\title{
POTATO CULTIVARS SUSCEPTIBILITY TO POTATO LATE BLIGHT (PHYTOPTHTORA INFESTANS)
}

\author{
A. RAZUKAS - J. JUNDULAS - R. ASAKAVICIUTE* \\ Voke Branch of Lithuanian Institute of Agriculture, Vilnius, Lithuania \\ Voke Branch of Lithuanian Institute of Agricultur \\ Žalioji a. 2, Traku Voke, O2232 Vilnius, Lithuania \\ (phone: +370-5-2645439; fax: +370-5-2645430) \\ e-mail: rita.asakaviciute@voke.lzi.lt \\ (Received $2^{\text {nd }}$ February 2007; accepted $23^{\text {th }}$ July 2007)
}

\begin{abstract}
The main aim of this research was to determine the susceptibility of Lithuanian selection potato cultivars to late blight. Late blight infection was different in potato groups with various maturities. In early potatoes disease spread was more intensive, and slower in late maturity cultivars. The intensity of potato blight spread in various maturity potato cultivars depends not only on their earliness, but their biologic traits as well. Late blight research has been conducted in the potato breeding program - for the creation of biological-mathematical prognosis models of late blight. Potato cultivar 'Aista' has high resistance to $P$. infestans. 'Aista' is recommended for growing on ecologic farms.
\end{abstract}

Keywords: potato, cultivars, late blight, resistance, ecologic farms

\section{Introduction}

Potato late blight, a disease caused by the oomycete pathogen Phytophtora infestans (Mont.) de Bary, is one of the world's most devastating plant diseases. Late blight was responsible for the European potato famine in the $19^{\text {th }}$ century, which caused the starvation deaths of more than one million people in Ireland alone. Despite its historic significance, none of the currently grown potato cultivars in the Europe have adequate late blight resistance. Currently, late blight is responsible for multibillion-euro losses annually in both potato and tomato production. Furthermore, in developing countries, where funds for purchasing fungicides are limited, late blight can completely eliminate the potato crop [1].

Resistance of plants to pathogens often depends on the activation of defence responses after pathogens attack. A key factor in this type of resistance is the perception of the pathogen by the host, which triggers the appropriate defense responses. When defence responses completely block pathogen development, the interaction between pathogen and plant is called incompatible. Genes from the pathogen that mediate recognition and activation of host defence responses leading to incompatible interactions are called avirulence genes [2]. Incompatible interactions are usually associated with a hypersensitive response in the host and a high degree of specificity between the pathogen genotype and the host genotype.

The subject of our studies is $P$. infestans, the causal agent of potato late blight and one of the economically most important pathogens of potato worldwide. P. infestans and potato interact according to the gene-for-gene model [3]. These $11 \mathrm{R}$-genes, which suggest the presence of 11 corresponding virulence or avirulence factors in $P$. infestans, and genetic analyses on both host and pathogen have been performed to confirm the gene-for-gene model in this pathosystem [4]. 
Agrometeorological conditions for the late blight spread in Lithuania emerges almost every potato growing season. The fungus infects leaves, stems and later all plant. As the result of sexual reproduction oospores formation in many countries was registered. Oospores can survive in the soil about ten years. Local fungus population turns to be more aggressive, virulent and late blight disease become more dangerous [5].

Potato cultivars genetic resistance to the $P$. infestans is one of the main achievements of potato breeding programs. Many wild potato species have field resistance to $P$. infestans. They have high genetic source importance for potato breeding [6]. The biophysical mechanisms controlling late blight susceptibility in potato cultivars are complex and can involve differences in leaf and tuber cell defence biochemistry, as well as canopy structure, leaf anatomical variation and vine maturation rates [7]. P. infestans have mutable features so it can overpass any resistance. When limited potato gene bank is used in potato breeding for resistance to the late blight programs, disease in can violate large potato cultivar's groups in the separate years. Potato cultivars which were described as resistant to $P$. infestans in Europe, today are hardly injured by the late blight [4].

Potato late blight fast development when conditions are suitable causes massive disease spread which is called disease epifitoty. Disease spread depends to meteorological conditions, high infection, and potato growing period at disease attack time. Late blight disease epifitoty can be presented in the diagram as letter $S$ curve. In the beginning of disease spread (bottom of the letter S) late blight development speed is low because of little infection. Disease development speed reaches the highest speed when disease development covers 50\% (middle of letter S). It's an epifitoty maximum. In the end of epifitoty (in the diagram - top of the letter S) disease development slows down, because only a little part of plant tissues has no injuries. In the years of late blight depression disease spread diagram is partial and in the muted disease development years diagram curve is lengthy long shape. $P$. infestans disease development curves shape can also give information about potato cultivar's susceptibility [8].

The objective of this research was to examine tuber and foliage susceptibility of commercial potato cultivars to potato late blight, disease development and spread in the potato field.

\section{Materials and methods}

Trials were performed at Voke Branch of the Lithuanian Institute of Agroculture, during the years 2003-2005. Potato cultivars of local selection were used in the trials: first early 'Venta', second early - 'Goda', 'Liepa', 'Vokè', 'Vaiva', main crop - 'Nida' and 'Mirta', late - 'Vilnia' and 'Aista'. In the year 2005 disease tests were performed with 30 potato cultivars. Standard cultivar was 'Izora'.

Potato breeding and seed production in Lithuania is performed at Voke Branch of Lithuanian Institute of Agriculture. It was started in 1958. The main potato breeding object is to produce very early potato cultivars resistant to the nematodes, the late blight and the main potato diseases. As the result of breeding work ten cultivars were produced: 'Mèta', 'Vilnia', 'Aista', 'Nida', 'Mirta', 'Goda', 'Venta', 'Vokè', 'Liepa', 'Vaiva'. Almost all are immune to the worst potato disease - wart (Synchtrium endobioticum Schilb.), to local pathotype of nematodes (Globodera rostochiensis Woll.) and late blight (Phytophtora infestans (Mont.) de Bary)). Other advantages - good yield, 
suitability for processing industry, excellent cookery qualities, good taste or attractive shape were the main items also in producing of Lithuanian potato cultivars.

Potato cultivar 'Vilnia'. The cultivar was bred at the Voke Branch of the Lithuanian Institute of Agriculture. Potato cultivar 'Vilnia' is in the Lithuanian potato list since 1981. The cultivar is medium late, growing season 96 days, can be grown under dry conditions. Potato tubers are long oval, the skin is red, and the flesh is yellow. The cultivar is very high yielding, starch content is $15-19 \%$. The cultivar is not susceptible to potato blight, resistant to virus diseases, to wart disease, potato $\mathrm{Ro}_{1}$ nematodes. Tubers are rather resistant to mechanical injuries, have good winter storage qualities.

Potato cultivar 'Voke'. The cultivar was bred in the Voke Branch of the Lithuanian Institute of Agriculture. 'Voké' is in the Lithuanian potato list since 1981. It is an early food potato cultivar. The bushes are low and compact. Its flowering is short, produces rather few flowers. The flowers are light violet. The tubers are not big; yellowish, oval with shallow eyes. The skin is hard. The pith is light yellow. The variety produces many tubers. The potatoes are very suitable for industrial processing. The output of commercial tubers is $95 \%$. Starch content is $15-17 \%$ and higher. The potatoes are palatable, boil soft, and do not get dark. The tubers contain little reducing sugars and thus are suitable for manufactured food production. It is especially suitable for potato dry industry, chips and crisps. Since the tubers contain very little mono sugars the products do not get brown, they are light yellow. The cultivar is resistant to potato blight, black leg, mosaic, is little affected by scabs, can be grown in all types of soil, but produces the highest yield on cultivated loamy soil. In dry summers the tubers are small. The potatoes are rather resistant to mechanical injuries, have good winter storage qualities.

Potato cultivar 'Nida'. The cultivar was bred at the Voke Branch of the Lithuanian Institute of Agriculture. 'Nida' is in the Lithuanian potato list since 1989. It is a medium early, food potato cultivar. Its bush is compact, the stems are tall and big. It flowers abundantly, the flowers are red-violet, and the flowering time is of medium length. The tubers are big, round with shallow, small eyes. The output of commercial tubers is $95 \%$. Starch content is $14-16 \%$. The potatoes are palatable, boil soft. The cultivar is resistant to wart disease, potato cyst $\mathrm{Ro}_{1}$ nematode, Solanum virus 14 , black leg. Medium resistant to potato late blight, has good resistance to $\mathrm{X}$ virus. The cultivar can be grown on different types of soil, is resistant to dry weather, does not require any special cultivation techniques, storage conditions are good. The cultivar is not affected by machine harvesting as it has a hard skin.

Potato cultivar 'Aista'. The cultivar was bred at the Voke Branch of the Lithuanian Institute of Agriculture. 'Aista' is in the Lithuanian potato list since 1989. This is a late, food potato cultivar. The bush is stretched out, the stems are tall. The flowers are white, of medium size. The cultivar flowers abundantly and for a long time. The tubers are big, yellowish, flat round with shallow eyes. The output of commercial tubers is $90 \%$. Starch content is high, to $21 \%$. The cultivar is good for starch industry. The potatoes are palatable. The boiled potatoes do not get dark, boil soft. The cultivar is resistant to wart disease, potato cyst nematode $\mathrm{Ro}_{1}$, late blight. The cultivar is resistant to drought, can be grown in all kinds of soil using proper cultivation techniques. The cultivar is resistant to mechanical injuries while harvesting; is of good storage quality.

Potato cultivar 'Mirta'. Potato cultivar 'Mirta' was developed at the Voke Branch of the Lithuanian Institute of Agriculture. 'Mirta' is in the Lithuanian potato list since 1994. It is a medium early, food potato cultivar. It has good taste and cooking 
characteristics, does not get brown after peeling and does not get black after cooking. Tubers are suitable for processing. Starch content is $15-18 \%$. The cultivar can produce high yields and quality tubers. The tubers are of medium size, their shape is oval round, eye depth is shallow. Skin colour and flesh colour is light yellow. The cultivar has a short flowering period and produces rather few flowers, of white colour. The cultivar is resistant to summer heat and dry weather conditions. It is resistant to potato cyst nematode and wart disease. The cultivar is resistant to late blight, black leg, and potato leaf roll virus infection. Storage characteristics under controlled conditions are excellent. The cultivar is suitable for chips industry.

Potato cultivar 'Venta'. The cultivar 'Venta' was bred at the Voke Branch of the Lithuanian Institute of Agriculture. It is in the Lithuanian potato list since 1997. The maturity of the cultivar 'Venta' is very early. Tubers are round, with medium-deep eyes. Skin and flesh colour is light yellow. Cooking characteristics are perfect. There is no browning after peeling. Taste is excellent. The cultivar is salad type. Starch content is up to $14-16 \%$. The cultivar 'Venta' is resistant to wart disease; it possesses good field resistance to the black leg, potato leafroll virus. Storage characters under controlled conditions are excellent.

Potato cultivar 'Vaiva'. Potato cultivar 'Vaiva' was bred at the Voke Branch of the Lithuanian Institute of Agriculture. It is in the Lithuanian potato list since 2000. The cultivar is early. Tubers are long oval, medium in size, with shallow eyes, without discoloration. Skin colour is red. Flesh is yellow. Taste is good. It is suitable for processing industry. Starch content varies from $13 \%$ to $17 \%$. The cultivar is resistant to potato cyst nematode $\mathrm{Ro}_{1}$ and wart disease. Foliage is fairly resistant and tubers fully resistant to late blight. The cultivar has good resistance to virus diseases. Storage characteristics are good.

Potato cultivar 'Goda'. Potato cultivar 'Goda' was bred at the Voke Branch of the Lithuanian Institute of Agriculture. It is in the Lithuanian potato list since 2001. The cultivar is early. Tubers are oval round, medium in size, with shallow eyes. Flesh and skin colour is light yellow. Sugar content is low. No discoloration after peeling and cooking. Suitable for chips industry. Starch content is to 16-17\%. The cultivar is resistant to potato cyst nematode $\mathrm{Ro}_{1}$, and wart disease. Foliage is fairy resistant and tubers fully resistant to the late blight. Storage is good.

Potato cultivar 'Meta'. The plants are compact, stems straight, flowers white. Tubers are light yellow, round, with shallow eyes, flesh colour is yellow. Starch content is $16 \%$. The variety is late and has good cooking characteristics. Is resistant to potato cyst nematode, cancer and late blight.

Potato cultivar 'Liepa'. The variety is early. The plants are compact, flowers are violet. Tubers are round, medium in size, with shallow eyes. Flesh and skin colours are light yellow. Sugar content is low. No discoloration after peeling and cooking. Starch content is to $20 \%$. Resistant to potato cyst nematode. Tubers are fully resistant to late blight.

Trials were set up in conformation with local agricultural potato practice. The dynamics of late blight spread was assessed every 7-10 days from the occurrence of first disease symptoms till top killing. 100 plants were tested. From every plot, 25 plants were tested. The potato vine infection level was scored according to the attack, few plants with lesions, $1-2$ lesions in a 10m radius; $0.5-1-5$ spots per plant; $1-5-10$ spots per plant; 5 - around 50 spots per plant or up to 1 in 10 leaflets with lesions; 10 - about $10 \%$ leaf area destroyed; up to 4 in 10 destroyed; nearly every leaflets with lesions, 
plants still retain normal from; 25 - about $25 \%$ leaf area destroyed; nearly every leaflet with lesions; plants retain normal from; the field still looks green; 50 - about $50 \%$ leaf destroyed; every plant with lesions; field still green but with brown spots; 75 - about $75 \%$ leaf area destroyed; field colour between green and brown; 95 - only a few leaves left, but stems are still green; 100 - all leaves dead or dying. Late blight data obtained from the trial field were scored in per cent: late blight spread assessed and late blight first early potato cultivar 'Venta' was used.

All four cultivars were tested and grown on soddy podzolic sandy loam soil in a crop rotation field of the breeding department. Trials were performed on soddy podzolic sandy loam soil. Potato field was fertilized with organic manure - $50 \mathrm{t} \mathrm{ha}^{-1}$ and with mineral fertilizers $-\mathrm{N}_{90} \mathrm{P}_{90} \mathrm{~K}_{90}$ during land cultivation in the spring. After that complex fertilizer Kemira Cropcare 10-10-20 was used - $500 \mathrm{~kg} \mathrm{ha}^{-1}$. Fertilizers composition $\mathrm{N}_{10} \mathrm{P}_{4} \mathrm{~K}_{17}$ with microelements: $\mathrm{MgO}-4,1, \mathrm{~S}-11,0, \mathrm{~B}-0,15, \mathrm{Cu}-0,1, \mathrm{Fe}-0,1, \mathrm{Mn}-$ 0,7, Mo - 0,01, Zn - 0,1, Se - 0,0006 \%. Soil natural fertility was medium: humus amount was low - 1,8-2,0 \%, low acidity - $\mathrm{pH}_{\mathrm{KCl}}$ 5,1-5,5, high phosphorus amount $\mathrm{P}_{2} \mathrm{O}_{5}-180-240 \mathrm{mg} / \mathrm{kg}$ and potassium amount $-\mathrm{K}_{2} \mathrm{O} 150-190 \mathrm{mg} \mathrm{kg}^{-1}$.

The results were analyzed statistically for randomized split-plot design and the Tukey test was used to verify the significance of differences at $\alpha=0.05$. Yield data were compiled from multiple harvest dates. All data were subjected to ANOVA.

\section{Results}

Meteorological conditions are very important factor for late blight disease. They have straight influence to the potato plant growth, but also to disease spread and development. The optimal conditions for late blight spread are higher than $75 \%$ comparative air humidity and $13^{\circ} \mathrm{C}$ temperature. High temperature - over $25^{\circ} \mathrm{C}$ and low temperature - below $10^{\circ} \mathrm{C}$ stops late blight development. For meteorological conditions discussion were used data from Voke Branch of Lithuanian Institute of Agriculture mobile meteorological Hardi Metpole station and Lithuanian State Hydro Meteorological Service (Table 1).

Table 1. P. infestans disease spread meteorological conditions

\begin{tabular}{l|c|c}
\hline \multicolumn{1}{c|}{ Date } & Mean air temperature, ${ }^{\mathbf{0}} \mathbf{C}$ & Precipitation, $\mathbf{~ m m}$ \\
\hline June average of 38 years & 15.8 & 77.0 \\
2003 & 15.2 & 62.0 \\
2004 & 14.1 & 122.0 \\
2005 & 15.0 & 59.0 \\
July average of 38 years & 16.9 & 78.0 \\
2003 & 19.7 & 92.0 \\
2004 & 16.7 & 46.0 \\
2005 & 19.1 & 69.0 \\
August average of 38 years & 16.3 & 68.0 \\
2003 & 16.8 & 105.0 \\
2004 & 18.1 & 97.0 \\
2005 & 16.7 & 201.0 \\
\hline
\end{tabular}

In the year 2003 susceptibility determination of potato cultivars were measured: late blight start data, disease development process and disease spread intensive dynamics.

The first symptoms of late blight in the field are small, light to dark green, circular to irregular-shaped water-soaked spots. These lesions usually appear first on the lower 
leaves. Lesions often begin to develop near the leaf tips or edges, where dew is retained longest. During cool, moist weather, these lesions expand rapidly into large, dark brown or black lesions, often appearing greasy (Fig. 1). The lesions are not limited by leaf veins, and as new infections occur and existing infections coalesce, entire leaves can become blighted and killed within just a few days. The lesions may expand down petioles and stems of the plant.

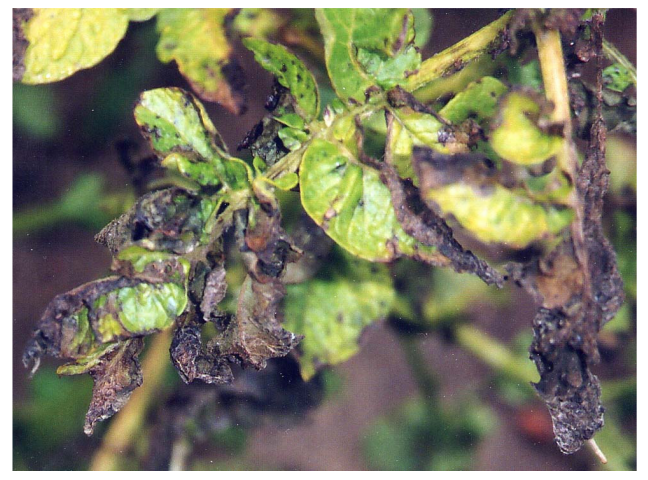

Figure 1. Potato plant with late blight (P. infestans)

The end of June - beginning of July, in 2003 was favourable for disease development, sporulation, infection and germination. Air humidity was from $76 \%$ up till $81 \%$. First disease symptoms were found in the cultivars 'Venta', 'Liepa' at $10^{\text {th }}$ of June. After one week in 'Nida' and 'Goda'. In 'Vilnia' and 'Aista' - in the end of June (Table 2). Disease affected leafs, steams and other plant parts. In June temperature was higher than average, precipitation was double $(92.0 \mathrm{~mm})$. August was warm and humid enough for potato blight development.

Table 2. Estimation of P. infestans in various potato cultivars, 2003.

\begin{tabular}{l|c|c|c|c}
\hline \multicolumn{1}{c|}{ Variety } & $\begin{array}{c}\text { First symptoms } \\
\text { display time }\end{array}$ & $\begin{array}{c}\text { Delay of first } \\
\text { symptoms (days) }\end{array}$ & $\begin{array}{c}\text { Disease rating when } \\
\text { rating of reference } \\
\text { variety } \mathbf{9 0 \%}\end{array}$ & $\begin{array}{c}\text { Final disease } \\
\text { rating, \% }\end{array}$ \\
\hline Venta & 1307 & 0 & $95.0 \mathrm{a}$ & $100.0 \mathrm{a}$ \\
Aista & 2007 & 7 & $3.2 \mathrm{~d}$ & $13.8 \mathrm{~d}$ \\
Goda & 2007 & 7 & $80.0 \mathrm{~b}$ & $100.0 \mathrm{a}$ \\
Liepa & 2007 & 7 & $80.0 \mathrm{~b}$ & $100.0 \mathrm{a}$ \\
Mirta & 2007 & 7 & $46.2 \mathrm{c}$ & $90.0 \mathrm{~b}$ \\
Nida & 2007 & 7 & $50.0 \mathrm{c}$ & $87.5 \mathrm{~b}$ \\
Voke & 2007 & 7 & $66.2 \mathrm{c}$ & $100.0 \mathrm{a}$ \\
Vilnia & 2007 & 7 & $8.2 \mathrm{~d}$ & $53.8 \mathrm{c}$ \\
& & & 1.24 & 2.05 \\
\hline
\end{tabular}

Late blight affect on various maturity potato cultivars was different. Disease spread was more intensive in early than in late maturity potato cultivars. Disease development intensity was low up till 24th of June $-0.17-19.15 \%$ when almost all cultivars had $100 \%$ infected plants. During one week disease intensity grew up $-16-45 \%$. In year 2003, late blight disease reached epifitoty (Fig. 2). Tested cultivars can be divided to groups according to disease development curves: 1)very susceptible to the late blight: 'Venta', 'Liepa', 'Voke', 'Vaiva', 2) medium susceptibility: 'Goda', 'Nida', 'Mirta'; 3) medium resistance: 'Vilnia', 'Aista'. 


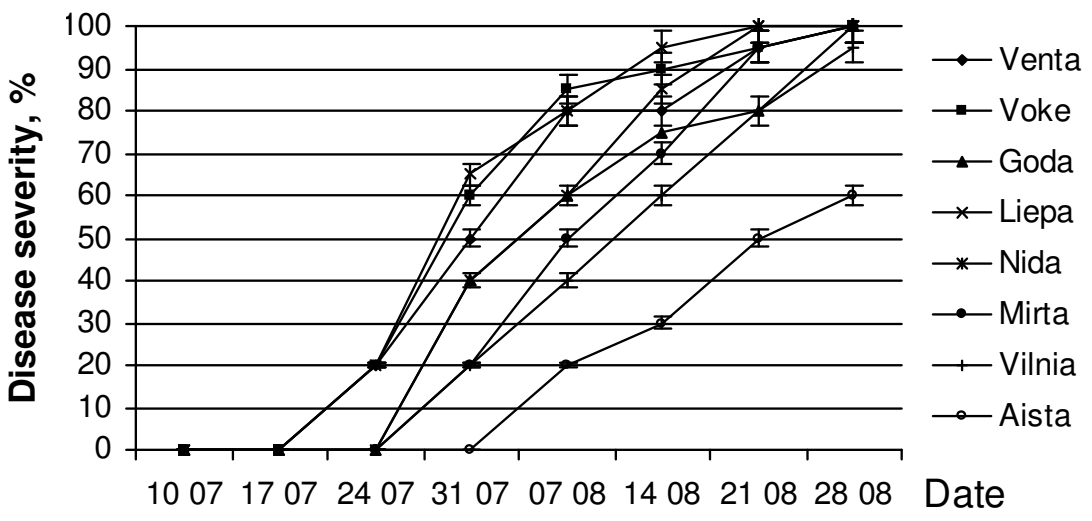

Figure 2. Potato blight development dynamics in various maturity potato cultivars, 2003.

In the year 2004 at the end of June - beginning of July conditions were favourable for late blight disease. It was found in all the places of potato foliage: plant leaves, steams and top of foliage. A number of scientists have an opinion that fungus population of late blight disease becomes more aggressive when first disease symptoms are found on the steams and top of the foliage. Rainy and warm weather during June and August was favourable for late blight (Table 1).

Late blight fungus first found in potato trials was identified in 'Venta' and 'Liepa' potato cultivars on $13^{\text {th }}$ of June. After one week in 'Nida' and 'Goda'. First disease symptoms in potato cultivar 'Vilnia' were found on $20^{\text {th }}$ of June, in 'Aista' $-30^{\text {th }}$ of June (Table 3).

Table 3. Estimation of P. infestans in various potato cultivars, 2004.

\begin{tabular}{l|c|c|c|c}
\hline \multicolumn{1}{c|}{ Variety } & $\begin{array}{c}\text { First symptoms } \\
\text { display time }\end{array}$ & $\begin{array}{c}\text { Delay of first } \\
\text { symptoms (days) }\end{array}$ & $\begin{array}{c}\text { Disease rating when } \\
\text { rating of reference } \\
\text { variety } \geq \mathbf{9 0 \%}\end{array}$ & $\begin{array}{c}\text { Final disease } \\
\text { rating, \% }\end{array}$ \\
\hline Venta & 1007 & 0 & $95.3 \mathrm{a}$ & $100.0 \mathrm{a}$ \\
Aista & 3107 & 28 & $31.3 \mathrm{~d}$ & $63.0 \mathrm{c}$ \\
Goda & 1707 & 7 & $71.8 \mathrm{~b}$ & $100.0 \mathrm{a}$ \\
Liepa & 1007 & 0 & $94.8 \mathrm{a}$ & $100.0 \mathrm{a}$ \\
Mirta & 1707 & 7 & $70.8 \mathrm{~b}$ & $100.0 \mathrm{a}$ \\
Nida & 1007 & 0 & $85.5 \mathrm{ab}$ & $100.0 \mathrm{a}$ \\
Voke & 1007 & 0 & 97.0 & $100.0 \mathrm{a}$ \\
Vilnia & 2407 & 14 & $52 . \mathrm{c}$ & $88.5 \mathrm{~b}$ \\
& & & 3.28 & 3.59 \\
\hline
\end{tabular}

In the middle of August susceptible potato cultivars ('Venta', 'Liepa', 'Nida') almost all foliage was dead. When more resistant potato cultivars ('Vilnia', 'Aista') foliage injuries covered 31.25-52.0\%. In end of August they had 21.5-27.0\% green leaves without fungicides application. The lowest infection speed (AIR) was in 'Aista' potato cultivar. The highest competitive area under disease intensity curve (RAUDPC) was in 'Liepa' and 'Vaiva' cultivars (0.59). The lowest RAUDPC was 'Aista' cultivar's. Cultivars 'Venta', 'Mirta', 'Nida' and 'Vilnia' for resistance to the late blight were classified as 4-6 according to the 1-9 points scale (Fig. 3). 


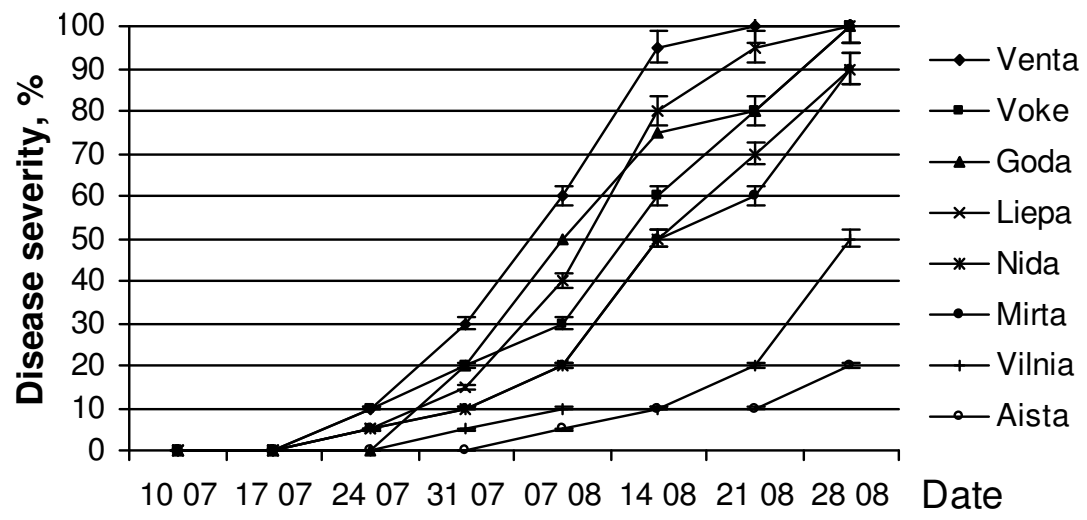

Figure 3. Potato blight development dynamics in various maturity potato cultivars, 2004.

In the year 2005 disease tests were performed with 30 potato cultivars. Standard cultivar was 'Izora'. In the end of June - beginning of July were favourable conditions for the late blight disease spread. Disease was found in the all places of foliage. Not only on the plant leafs, but also on the steams and top of foliage. Rainy and warm weather during June and August months was favourable for disease development (Table 1).

Late blight fungus first found in potato trials was identified in 'Izora', 'Venta', 'Gloria', 'Impala', 'Fresco', 'Zukovkij rannij', 'Bintje', 'Provita' and 'Planta' potato cultivars on 13th of June. After one week in 'Nida' and 'Goda'. First disease features in 'Vilnia' potato cultivar was found at 20th of June, in 'Aista' - 30th of June. 2005 year was late blight disease epifitoty. Diagrams representing late blight development are letter S curves. Up till beginning of August disease development was not intensive $0.75-45.0 \%$ when late blight infection had $100 \%$ plants. During one week disease developed fast - injuries intensity grew up from 3.2 till 95\%. Susceptible potato cultivars 'Venta' and 'Liepa' in middle of August died almost all foliage, accordingly 95.0 and $80.0 \%$. When more resistant 'Vilnia' and 'Aista' potatoes foliage injuries were accordingly 8.25 and $3.2 \%$. In the end of August they had 46.25 and $86.25 \%$ green leaves even when fungicides were not applied. The lowest disease infection speed (AIR) was got in 'Kuras' and 'Aista' potato cultivars. The highest competitive area under disease intensity curve (RAUDPC) was got in cultivars 'Izora', 'Venta' and 'Bintje' 0.49, 'Liepa' - 0.45, 'Gloria' - 0.44. The lowest RAUDPC was 'Kuras' and 'Aista' cultivar's -0.03 .

Tested potato cultivars depending to the late blight disease development curves are divided to these groups:

- very susceptible - 'Izora', 'Fresco', 'Zukovskij raanij', 'Austonia', 'Bintje', 'Gloria', 'Venta', 'Impala', 'Liepa' and 'Provita';

- medium susceptibility - 'Voke', 'Sante', 'Planta', 'Miriam', 'Nida', 'Mirta', 'Escort', 'Laura', 'Sierra', 'Lady', 'Rosetta', Oleva', 'Danva', 'Sava', 'Hermes', 'Vilnia', 'Raja', 'Asterix' and 'Saturna';

- medium resistance - 'Aista' and 'Kuras'.

In the years 2003 and 2005 of disease tests meteorological conditions were not favourable for late blight disease spread and development. Warm and dry weather with 
high temperatures closed all possibilities to find disease in the trials plots - there was no $P$. infestans infection and sporulation. This year was late blight depression year.

\section{Discussion}

Late blight is caused by the fungus Phytophthora infestans (Mont.) de Bary. Unlike most pathogenic fungi, the late blight fungus cannot survive in soil or dead plant debris. For an epidemic to begin in any one area, the fungus must survive the winter in potato tubers (culls, volunteers), be reintroduced on seed potatoes or tomato transplants, or live spores must blow in with rainstorms. Disease development is favoured by cool, moist weather. Nights in the 50's and days in the 70's accompanied by rain, fog or heavy dew are ideal. Under these conditions, lesions may appear on leaves within 3-5 days of infection, followed by the white mould growth soon thereafter. Spores formed on the mould are spread readily by irrigation, rain and equipment. They are easily dislodged by wind and rain and can be blown into neighbouring fields within 5-10 miles or more, thus beginning another cycle of disease [9].

Infection of potato tubers arises from spores that develop on foliage. Tubers exposed by soil cracking or erosion of hills may come in contact with spores washed down from infected leaves and stems by rainfall or irrigation. Tubers infected during the growing season may partially decay before harvest. Tuber infection may also occur at harvest when tubers contact living spores remaining on infected vines. Little if any tuber-totuber spread of late blight occurs during storage if tubers are kept under cool, wellventilated conditions.

Potato breeding and initial seed production of new cultivars in Lithuania is performed at the Voke Branch of the Lithuanian Institute of Agriculture. The key objective in potato breeding is to create high yielding, early or medium early potato cultivars [10].

The newly developed potato varieties are resistant to wart disease and $\mathrm{RO}_{1}$ patotype of nematodes. The other advantages such as high resistance to fungal and bacterial diseases and viruses are given a high priority too in Lithuanian potato breeding.

Analyzing the late blight development helps to determine disease development differences not only between various susceptibility potato cultivars and maturity groups, but also to find differences in the same potato cultivar every separate research year. Meteorological conditions influence research to the late blight development was performed in various potato maturity groups and susceptibility to disease every vegetation period. The main influence to disease development process had precipitation amount, average day temperature, humidity from the beginning of disease spread up till the highest injury point.

A group of scientists have opinion that it's necessary to apply few methods for potato cultivars susceptibility to the late blight determination. In the future potato cultivars and hybrids of potato breeding programs have to be tested not only in the field conditions with the natural late blight infection, but also at the laboratory - making artificial infection settings [3,11, 12].

Data of this research can be used not only in the potato breeding and growing work, but also in the fungicides application programs and models.

Potato blight development intensity in various potato cultivars depended not only to their maturity group, but also to their genetic and biologic features. The most resistant to the late blight potato cultivars were 'Vilnia', 'Aista' and 'Kuras'. Potato cultivars 
according to the susceptibility to the late blight are divided to three groups: very susceptible (B1), medium susceptibility (B2) and medium resistance (B3).

The cultivated potato (Solanum tuberosum) originates from the Lithuania, where there are several other species of the genus Solanum. The potato blight fungus also is thought to have its centre of origin in this region, so it is sensible to seek sources of genetic resistance to the pathogen in the wild potato plants of this region. Four major resistant genes (termed R genes) were discovered and were introduced successively into commercial cultivars. However, within a few years of each $\mathrm{R}$ gene being introduced widely into potato cultivars, the fungus was found to be able to attack these plants - the resistance was overcome by new strains (termed physiologic races) of the pathogen that developed in response to the selection pressure imposed by the specific $\mathrm{R}$ genes. Thus, race 1 of the pathogen could cause disease of potato cultivars carrying the $\mathrm{R} 1$ gene, and so on. With four $\mathrm{R}$ genes there are a possible 16 combinations - you can breed potatoes with, for example, R1 and R2, or R1 and R4, or R1, R2, R3 and R4, etc. But eventually a pathogen race would emerge that had the corresponding virulence genes to overcome all these.

For long-term control, this form of resistance breeding based on a few "major resistance genes" seems destined to fail. So, many plant breeders now prefer to develop cultivars that have "polygenic" or "field resistance" to the pathogen. Such plants have combinations of several "minor" genes, none of which gives absolute resistance, but together they slow the rate of development of the fungus and enable the plant to tolerate infection.

Like many members of the Oomycota, $P$. infestans has two mating types, termed A1 and A2. It can undergo sexual reproduction only if both mating types are present in a population. Both mating types occur in Mexico, near the centre of origin of Solanum and thus presumably of its pathogen $P$. infestans. However, in Europe only the A1 strain was known to occur - presumably because it was introduced by chance on potatoes imported from elsewhere. Then, in 1978, the A2 mating type was discovered in Britain and is now also found commonly in much of continental Europe. How it arrived or originated here is still unclear, but this has the important consequence that the fungus can now generate genetic variation via recombination. The stage is now set for even more rapid emergence of new pathogenic variants, to overcome our continuing attempts to control this disease.

\section{Management}

Late blight is controlled by eliminating cull piles and volunteer potatoes, using proper harvesting and storage practices, and applying fungicides when necessary. Air drainage to facilitate the drying of foliage each day is important. Under marginal conditions, overhead sprinkler irrigation can favour late blight; in Tulelake under solid set sprinklers, conditions conducive to late blight development are enhanced by day time irrigation but not night time irrigation.

Plant certified seed tubers. When late blight has developed on foliage and tubers are at risk of infection, make sure that vines are completely dead for 2 to 3 weeks before harvest [13]. Phytophthora infestans does not survive very long in dead foliage.

In districts that are commonly subjected to outbreaks of late blight, preventive applications of fungicides are advised when environmental conditions are favourable for the disease. Continue fungicide applications at 7- to 10-day intervals as conditions 
require. Shorter intervals may be needed under cool, rainy conditions. In interior districts where late blight occurs sporadically, apply fungicides when late blight lesions appear in the field or in nearby plantings [14].

\section{Conclusions}

Late blight disease fungus $P$. infestans development, sporulation and multiplication tests were performed in the field tests with over than thirty potato cultivars of very different genetic resources of European potato breeders.

Potato late blight disease development was different in the research years and depended from meteorological factors.

Two of five research years (2003 \& 2005) P. infestans have not showed evidence, disease was not registered in the test plots. Late blight epitothy were 2003 and 2004 years. The disease growth was very intensive and in the end of vegetation period in all tested potato cultivars was $100 \%$. Disease spread depending to the meteorological conditions was in the first or second decades of June. Potato plants started flowering (60-69 growing period). Restrained late blight disease development was 2005 year, disease intensity was $67,75 \%$.

After testing results it was determined that the most of tested cultivars had medium susceptibility, only cultivars 'Kuras' and 'Aista' had resistance to the late blight.

Potato cultivars resistance to the late blight research is very important. Due to fast $P$. infestans fungus evolution in Europe prognosis can be given that imported from EC countries potato cultivar's resistance can change, because late blight disease fungus population in separate country is different. Importing new potato cultivars, their resistance depending to the fungus $P$. infestans population racial constitution influence to the cultivar's susceptibility to the late blight has to be always tested.

Late maturity cultivars had higher resistance to disease. Potato late blight disease spread intensity in the different cultivars depended not only from their maturity but also from their individual genotype.

Potato cultivar 'Aista' has high resistance to $P$. infestans. 'Aista' is recommended for growing on ecologic farms.

\section{REFERENCES}

[1] Rubio-Covarrubias, O.A., Douches, D.S., Hammershmidt, R., daRocha, A., Kirk, W.W. (2005): Effect of Temperature and Photoperiod on Symptoms Associated with Resistance to Phytophthora infestans After Leaf Penetration in Susceptible and Resistant Potato Cultivars. - Amer. J. of Potato Res. 82: 139-146.

[2] Bisognin, D.A., Douches, D.S., Buszka, L., Bryan, G., Wang, D. (2005): Mapping Late Blight Resistance in Solanum microdontum Bitter. - Crop Sci. 45: 340-345.

[3] Lee, T., Robold, A., Testa, A., Klooster, J.W., Govers, F. (2001): Mapping of Avirulence Genes in Phytophthora infestans With Amplified Fragment Length Polymorphism Markers Selected by Bulked segregant Analysis. - Genetics 157: 949-956.

[4] Song, J., Bradeen, J.M., Naess, S.K., Raasch, J.A., Wielgues, M., Haberlach, G.T., Liu, J., Kuang, H., Phillips, S.A., Buell, C.R., Helgeson, J.P., Jiang, J. (2003): Gene RB cloned from Solanum bulbocastanum confers broad spectrum resistance to potato late blight. - PNAS 100(16): 9128-9133.

[5] Judelson, H.S., Blanco, F.A. (2005): The spores of Phytophthora: Weapons of the plant destroyer. - Nature Rev. Microbiol. 3: 47-58. 
[6] Kamoun, S. (2001): Nonhost resistance to Phytophthora: Novel prospects for a classical problem. - Curr. Opin. Plant Biol. 4: 295-300.

[7] Kirk, W.W., Felcher, K.J., Douches, D.S., Coombs, J., Stein, J.M., Baker, K.M., Hammerschmidt, R. (2001): Effect of Host Plant Resistance and Reduced Rates and Frequencies of Fungicide Application to Control Potato Late Blight. - Plant Disease 85: 1113-1118.

[8] Hansen, J.G., Koppel, M., Valskyte, A., Turka, I., Kapsa, J. (2005): Evaluation of foliar resistance in potato to Phytophthora infestans based on an international field trial network. - Plant Pathology 54: 169-179.

[9] Mukalazi, J., Adipala, E., Sengooba, T., Hakiza, J.J., Olanya, M. Kidanemariam, H.M. (2001): Variability in Potato Late Blight Severity and its Effect on Tuber Yield in Uganda. - African Crop Science Journal 9(1): 195-201.

[10] Haynes, K.G., Weingartner, P.D. (2004): The Use of Area Under the Disease Progress Curve to Assess Resistance to Late Blight in Potato Germplasm. - American Journal of Potato Research 81: 137-141

[11] Razukas, A., Jundulas, J. (2005): Potatoes breeding in Lithuania. - Scientific works of the Lithuanian Institute of Horticulture 24(3): 187-195.

[12] Asakaviciute, R., Razukas, A., Jundulas, J. (2006): Lithuanian potato cultivars resistance to late blight (Phytophthora infestans). Third International Conference on Non Chemikal Crop Protection Methods, Lille, France: 705-708.

[13] Swiezynski, K.M., Domanski, L., Zarzycka, H., Zinoch-Guzowska, E. (2000): The reaction of potato differentials to Phytophthora infestans isolates collected in nature. Plant Breeding 119: 119-126.

[14] Schepers, H.T.A.M. (2000): The development and control of Phytophthora infestans in Europe in 1999. - PAV-Special Report. 6: 10-18. 